\title{
THYROGLOBULIN AS A POSSIBLE PREDICTOR OF DOSES RADIOIODINE THERAPY IN HYPERTHYROIDISM
}

(C) by Acta Medica Saliniana ISSN 0350-364X

Type of manuscript: Professional papers

\section{Title:}

THYROGLOBULIN AS A POSSIBLE PREDICTOR OF DOSES RADIOIODINE THERAPY IN HYPERTHYROIDISM

\section{Authors:}

Azabagić Salih

DOI: $10.5457 / 445$

\section{Afiliations:}

Department of Endocrinology,

University Clinical Centre Tuzla

Received: 29.11.2017.

Corresponding author:

Salih Azabagić, MD,

Department of Endocrinology, Clinic of Internal Diseases, University Clinical Centre Tuzla, Bosnia and Herzegovina. e-mail: salihazabagic@hotmail.com

Introduction According to guidelines for the management of hyperthyroidism, patients with hyperthyroidism should be treated with radioactive iodine, antithyroid drugs, or thyroidectomy. Oral administration of radioiodine is a safe and cost effective treatment option for patients with toxic multinodular goiter (TMG)/toxic adenoma (TA) or Grave's disease (GD).

The aim of the study was to evaluate the use of thyroglobulin values as a possible predictor of a dose of radioiodine therapy (RAI) in hyperthyroidism in patients GD, TA and TMG.

Results The study included 105 patients (14.4\% males and 85.6\% females). The average duration of the disease was 9 years. Graves's disease is registered among $50.68 \%$, toxic multinodular goiter among $30.83 \%$ and toxic adenoma among $18.49 \%$ of patients. Patients were divided into four groups, and they received four doses of radioiodine therapy: $10 \mathrm{mCi}, 15 \mathrm{mCi}, 20 \mathrm{mCi}$ and $25 \mathrm{mCi}$. The values of thyroglubulin were measured before RAI, and in period of one, three and six months after the therapy.

Conclusion It can be concluded that the higher average value of thyroglobulin before therapy suggests the need for administering a higher doses of RAI, so determination of thyroglobulin levels in serum, may serve as a good predictor to assist in monitoring the administered dose of RAI in patients with hyperthyroidism.

Key words: Radioiodine therapy, hyperthyroidism, Graves' disease, toxic adenomas, toxic multinodular goiter.

\section{INTRODUCTION}

Hyperthyroidism is characterized by increased thyroid hormone synthesis and secretion from the thyroid gland, whereas thyrotoxicosis refers to the clinical syndrome of excess circulating thyroid hormones, irrespective of the source. The most common cause of hyperthyroidism is Graves' disease, followed by toxic nodular goiter (1). Guidelines for the management of hyperthyroidism and other causes of thyrotoxicosis were developed by the American Thyroid Association (ATA) and the American Association of Clinical Endocrinologists, and these were updated in 2016 (2, 3). According to these recommendations patients with hyperthyroidism should be treated with any of the following modalities: radioactive iodine (RAI), antithyroid drugs, or thyroidectomy. Oral administration of radioiodine is a safe and cost effective treatment option for patients with toxic multinodular goiter/toxic adenoma or Grave's disease (4). Debate ensues over whether a fixed dose of RAI or a variable individualized dose should be used (5).
The aim of the study was to evaluate the use of thyroglobulin values as a predictor of a dose of radioiodine therapy in hyperthyroidism in patients with Graves' disease (GD), toxic adenomas (TA) and toxic multinodular goiter (TMG).

\section{PATIENTS AND METHODS}

In this prospective-retrospective study, were analyzed 105 patients with clinically proven manifestation of hyperthyroidism, treated at the Department of Radiology and Nuclear Medicine at the University Clinical Center Tuzla. The patients have been clinically proven as Graves' disease, toxic adenomas, and toxic multindular goiter. We collected the potential influencing factors, including demographic data (age, sex, type and duration of the disease), iodine intake, antithyroid drugs (ATD) taking, thyroid texture, complications of hyperthyroidism, physical and laboratory examinations: tri-iodothyronine (T3), thyroxin (T4), thyroid-stimulating hormone (TSH), thyroglobulin (Tg) and thyroglobulin antibody (TgAb). Clinical 
examination, blood samples, thyroid ultrasounds and scintigraphy were performed before radiotherapy, and in period of one, three and six months after the therapy. Patients were divided into four groups, and they received four doses of radioiodine therapy: $10 \mathrm{mCi}, 15 \mathrm{mCi}, 20 \mathrm{mCi}$ and $25 \mathrm{mCi}$.

Top of Form

\section{RESULTS}

The study included 105 patients (14.4\% males and $85.6 \%$ females), with average age $52.6 \pm 18$ for males, and $52.3 \pm 13$ for female's patients. The average duration of the disease was 9 years. Graves's disease is registered among $50.68 \%$, toxic multinodular goiter among $30.83 \%$ and toxic adenoma among $18.49 \%$ of patients.

In patients before application of RAI of $10 \mathrm{mCi}$, the mean value of Tg was 89.4, before the application of dose of 15 $\mathrm{mCi}$ the mean value for $\mathrm{Tg}$ was 98.6. Furthermore, the mean value of $\mathrm{Tg}$, before application of RAI of $20 \mathrm{mCi}$ was 148.3 , and 375,9 before application of $25 \mathrm{mC}$ RAI. Results has showed that before application of RAI the lowest mean value of $\mathrm{Tg}$ (48.0) had the patients whom the dose of $10 \mathrm{mCi}$ RAI was subsequently administered, while the highest mean value of $\mathrm{Tg}$ (235.0) was in patients in whom dose of $25 \mathrm{mCi}$ RAI administered.

After the application of RAI, values of $\mathrm{Tg}$ were monitoring at three periods: after months and after three and six months (Table 1).

Table 1. Values of thyroglobulin month, three and six months after radioiodine therapy

\begin{tabular}{|l|c|c|c|c|c|c|c|c|c|c|c|c|}
\hline $\begin{array}{l}\text { Doses of } \\
\text { radioio- } \\
\text { dine }\end{array}$ & \multicolumn{3}{|c|}{$10 \mathrm{mCi}$} & \multicolumn{3}{c|}{$15 \mathrm{mCi}$} & \multicolumn{3}{c|}{$20 \mathrm{mCi}$} & \multicolumn{2}{c|}{$25 \mathrm{mCi}$} \\
\hline $\begin{array}{l}\text { Months of } \\
\text { therapy }\end{array}$ & TG 1. & TG 3. & TG 6. & TG 1. & TG 3. & TG 6. & TG 1. & TG 3. & TG 6. & TG 1. & TG 3. & TG 6. \\
\hline $\begin{array}{l}\text { Arithme- } \\
\text { tic mean } \\
\text { value }\end{array}$ & 52,7 & 38,0 & 31,8 & 124,2 & 529,9 & 326,4 & 235,3 & 259,1 & 185,0 & 397,5 & 486,7 & 469,1 \\
\hline $\begin{array}{l}\text { Standard } \\
\text { Deviation }\end{array}$ & 41,6 & 49,9 & 41,1 & 157,7 & 1048,0 & 930,2 & 499,7 & 506,4 & 419,3 & 346,1 & 337,0 & 497,4 \\
\hline $\begin{array}{l}\text { Min. } \\
\text { Max. }\end{array}$ & 115,0 & 135,0 & 124,0 & 509,0 & 3475,0 & 3894,2 & 1733,0 & 1752,0 & 1684,0 & 1050,0 & 1030,0 & 2067,0 \\
\hline $\begin{array}{l}\text { Range of } \\
\text { variation }\end{array}$ & 113,0 & 132,0 & 121,0 & 503,0 & 3466,5 & 3894,0 & 1703,0 & 1745,0 & 1683,0 & 1039,9 & 909,1 & 2064,8 \\
\hline
\end{tabular}

The mean value of Tg one month after the application of RAI were; 52.7 after application of $10 \mathrm{mCi} ; 124.2$ for 15 mCi; 235, 3 after $20 \mathrm{mCi}$ and 397.5 after $20 \mathrm{mCi}$ of RAI. Results has showed that one month after the application of RAI the lowest mean value of Tg had the patients whom the dose of $10 \mathrm{mCi}$ RAI was subsequently administered, while the highest mean value of Tg was in patients in whom dose of $25 \mathrm{mCi}$ RAI administered.

The mean value of Tg three months after the application of RAI were; 38.0 after application of $10 \mathrm{mCi} ; 529.9$ after $15 \mathrm{mCi} ; 259.1$ after $20 \mathrm{mCi}$ and 486.7 after $20 \mathrm{mCi}$ of RAI. Results has showed that three months after the application of RAI the lowest mean value of $\mathrm{Tg}$ had the patients whom the dose of $10 \mathrm{mCi}$ RAI was subsequently administered, while the highest mean value of Tg was in patients in whom dose of $25 \mathrm{mCi}$ RAI administered.

The mean value of Tg six months after the application of RAI were; 31.8 after application of $10 \mathrm{mCi} ; 326.4$ after
$15 \mathrm{mCi} ; 185.3$ after $20 \mathrm{mCi}$ and 469.1 after $20 \mathrm{mCi}$ of RAI. These results also has showed that three months after the application of RAI the lowest mean value of Tg had the patients whom the dose of $10 \mathrm{mCi}$ RAI was subsequently administered, while the highest mean value of $\mathrm{Tg}$ was in patients in whom dose of $25 \mathrm{mCi}$ RAI administered.

The mean value of Tg before therapy was 196.7, and after the period of six after the RAI was 301.1 (Figure 1.). The results has showed that after administration of therapy with radioactive iodine, the average $\mathrm{Tg}$ value increased after a one and three months, but after six months there was a mild drop in the average Tg value.

In order to predict the final outcome of RAI, multinominal logistic regression analysis has showed the effect of $\mathrm{Tg}$ : increasing the value of $\mathrm{Tg}$ levels in serum, for each unit leads to increasing the chances of developing hyperthyroidism for 1.004 times, in relation to euthyroidism. 


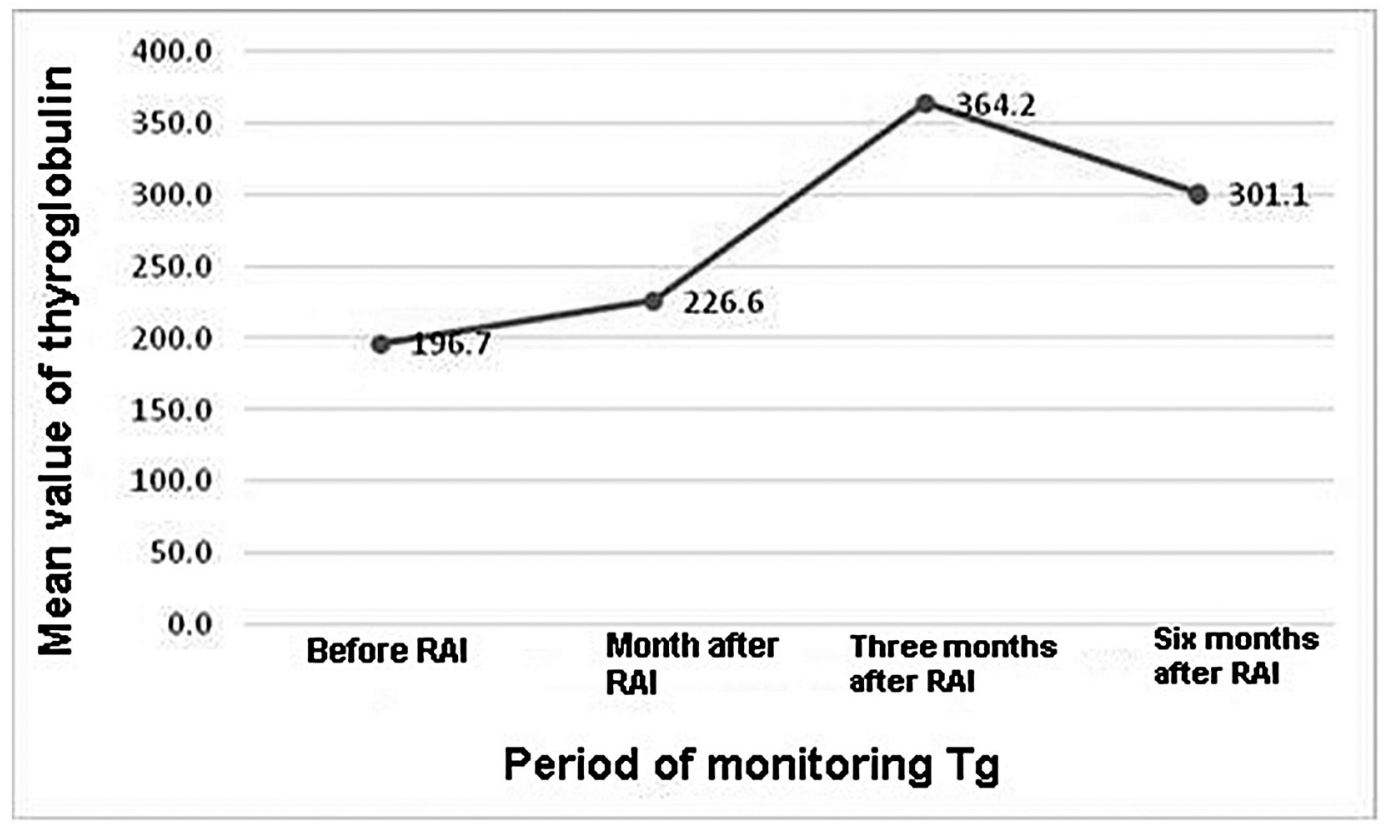

Figure 1. The mean value of thyroglobulin before radioiodine therapy, and after one, three and six months

\section{DISCUSSION}

A literature review by Wang and Qin of randomized, controlled trials indicated that compared with antithyroid drugs, radioiodine treatment has a higher hyperthyroid cure rate, lower recurrence rate and lower incidence of adverse events. However, it was also found to carry a greater risk for the development or worsening of ophthalmopathy and for hypothyroidism (6). However, radioiodine is increasingly used as the definitive treatment of choice in most patients with hyperthyroidism (7). After a single radioiodine administration, patients may become hypothyroid, euthyroid, or remain hyperthyroid (8). In our study, the most common complication was hyperthyroidism, and the prediction factors were age, thyroglobulin TG duration of the disease and dose of radioactive iodine, meaning that the complications of hyperthyroidism are more frequent at older age patients, higher Tg values, and longer duration of the disease. Dose of radioactive iodine also had a significant effect on the outcome of therapy of hyperthyreosis. Larger doses of I-131 are required for management of toxic nodular goiters and the authors rarely give less than $20 \mathrm{mCi}$. In larger multinodular goiters, doses in the range of 30 to 75 mCi may be required $(9,10)$. The ATA recommends a wide range of RAI dosage for clinicians administering RAI, with recommended doses ranging from 370$555 \mathrm{MBq}$ for GD and $370740 \mathrm{MBq}$ for TMNG/TA. This recommendation provides liberty to prescribing clinicians to opt for doses according to individual centre experience and clinical estimation of thyroid volume.

The general conclusion of this study is that the reduction in the dose of radioactive iodine greatly increases the chance of the occurrence of hyperthyroidism in relation to euthyroidism (11).
Determining the level of Tg before and after RAI in these patients, we concluded that in all periods (one, three and six months after RAI), lowest mean value of $\mathrm{Tg}$ had the patients whom the dose of $10 \mathrm{mCi}$ RAI was subsequently administered, while the highest mean value of Tg was in patients in whom dose of $25 \mathrm{mCi}$ RAI administered.

\section{CONCLUSION}

It can be concluded that the higher average value of thyroglobulin before therapy suggests the need for administering a higher doses of RAI, so determination of thyroglobulin levels in serum, may serve as a good predictor to assist in monitoring the administered dose of RAI in patients with hyperthyroidism.

\section{SAŽETAK}

Uvod Prema vodičima za liječenje hipertireoze, pacijente sa hipertireozom treba tretirati sa terapijom radioaktivnim jodom, antitireoidnim lijekovima te tireoidektomijom. Oralna administracija radiojodida je siguran i efektivan tretman za pacijente sa toksičnom multinodularnom strumom (TMS), toksičnim adenomom (TA) te Gravesovom bolešću (GB).

Cilj studije je praćenje vrijednosti tireoglobulina, kao mogućeg prediktora u određivanju doze radiojodid terapije (RAI) u liječenju hipertireoidizma kod gore navedenih bolesti.

Rezultati Studija je uključila 105 pacijenata (14.4\% muškaraca i 85.6 \% žena). Prosječno trajanje bolesti je bilo 9 godina. GB je registrovana kod 50.68\%, TMS kod $30.83 \%$ i TA kod $18.49 \%$ bolesnika. Pacijenti su 
podijeljenji u četiri grupe, kojima su apliciran četiri doze RAI; $10 \mathrm{mCi}, 15 \mathrm{mCi}, 20 \mathrm{mCi}$ i $25 \mathrm{mCi}$. Vrijednosti tireoglobulina su mjerene u krvi prije apliciranja doze, te mjesec, tri i šest mjeseci nakon apliciranja RAI.

UciljudasepredvidiishodRAI, urađenajemultinomnalna logistička regresiona analiza, koja je pokazala efekat Tg; za svako jedinično povećanje vrijednosti Tg u serumu, povećala se šansa za nastanak hipertireoidizma 1.004 puta, u odnosu na eutireoidizam.

\section{REFERENCES}

1. De Leo S, Lee SY, Braverman LE. Hyperthyroidism. Lancet 2016; 388: 906-918.

2. Bahn Chair RS, Burch HB, Cooper DS, et al. Hyperthyroidism and other causes of thyrotoxicosis: management guidelines of the American Thyroid Association and American Association of Clinical Endocrinologists. Thyroid 2011; 21(6):593-646.

3. Ross DS, Burch HB, Cooper DS, et al. 2016 American Thyroid Association Guidelines for Diagnosis and Management of Hyperthyroidism and Other Causes of Thyrotoxicosis. Thyroid 2016; 26 (10):1343-1421.

4. Ross DS. Radioiodine Therapy for Hyperthyroidism. N Engl J Med 2011; 364(6): 52-550.

5. Abraham P, Acharya S.vCurrent and emerging treatment options for graves' hyperthyroidism. Ther Clin Risk Manag 2010; 6(1): 29-40.

6. Wang J, Qin L. Radioiodine therapy versus antithyroid drugs in Graves' disease: a meta-analysis of randomized controlled trials. Br J Radiol 2016; 89: 20160418.
Zaključak Možemo zaključiti da veće prosječne vrijedosti tireoglobulina u serumu kod pacijenata prije terapije, ukazuju na potrebu i za primjenom veće doze radiojodid terapije, tako da određivanje tireoglobulina u serumu može poslužiti kao prediktor primijenjene doze RAI u liječenju pacijenata sa hipertireozom.

Ključne riječi: Radiojodid terapija, hipertireoidizam, Gravesova bolest, toksični adenoma, toksična multinodularna struma

7. Abraham P, Acharya S. Current and emerging treatment options for Graves' hyperthyroidism. Ther Clin Risk Manag 2010;6:29-40.

8. Marcocci C, Gianchecchi D, Masini I, Golia F, Ceccarelli C, Bracci E et al. A reappraisal of the role of methimazole and other factors on the efficacy and outcome of radioiodine therapy of Graves' hyperthyroidism. J Endocrinol Invest 1990;13(6):513-20.

9. Hamburger JI, Hamburger SW. Diagnosis and management of large toxic multinodular goiters. J Nucl Med 1985;26(8):888-92.

10. Meier DA, Dworkin HJ. The autonomously functioning thyroid nodule. J Nucl Med 1991;32(1):30-2.

11. Cheah SK, Aljenaee K, Muhammad N, Gavigan L, Dooley $\mathrm{M}$, et al. Outcomes Following Fixed Dose Radioactive Iodine Therapy (RAI) in Hyperthyroid Patients with Grave's Disease and Toxic Nodular Disease. Endocrinol Metab Int J 2016; 3(6): 00070.
Scan this QR code with your mobile device for instant access to the current Issue of Acta Medica Saliniana

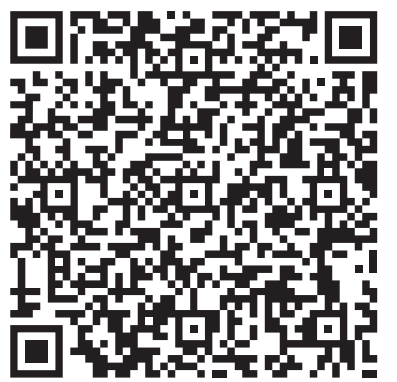

